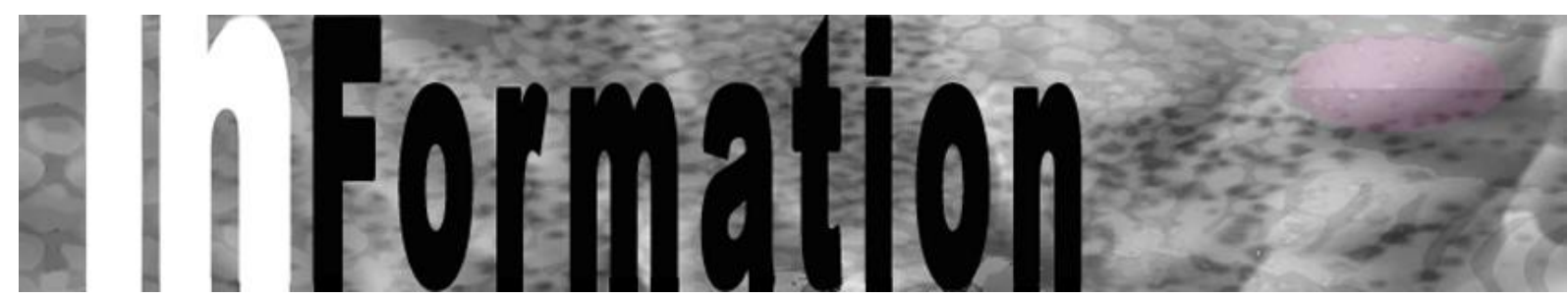

Nordic Journal of Art and Research

ISSN: 1893-2479

www.artandresearch.info

\title{
\#KunstInnsatsen:
}

\section{Estetiske erfaringer og skjønnsvurderinger ved asylmottak}

\author{
Jon Arnesen ${ }^{1}$ \& Rikke G. Gjærum ${ }^{2}$ \\ Universitetet i Tromsø, Høgskolen i Oslo og Akershus
}

\begin{abstract}
Sammendrag: Artikkelen omhandler et knippe kunstdidaktikeres skjønnsutøvelse i møte med et asylmottaks beboere. Forskerne beskriver og fortolker disse kunstdeltakernes skjønnsutøvelse og diskuterer hvordan denne skjønnsutøvelsen omsatt i en kunstpraksis kan inngå i utviklingen av det kulturelle demokrati. Studien bygger på dybdeintervju av syv strategisk utvalgte informanter. Empirien fortolkes innen et fenomenologisk forskningsdesign og diskuteres i lys av Aristoteles' phronesisbegrep' og Rancières teori om sanselighetens politikk og demokratiske forståelse av samfunnets fordeling av det sanselige.
\end{abstract}

Nøkkelord: Frivillig arbeid, kunst, asylmottak, estetiske opplevelser, fronesis, sanselighet

\section{Kontekstualisering og fokus}

Høsten 2015 dekket et internasjonalt pressekorps daglig krigshandlinger i Syria og formidlet fortellinger om mennesker i krise og som levde under uverdige livsforhold. Det utviklet seg etterhvert en massiv folkevandring i Europa, og mange ønsket seg til Norge. Mange, inkludert artikkelforfatterne ble utfordret på hva vi som enkeltmennesker kan bidra med i møte med enslige og familier på flukt over Middelhavet og langs europaveiene nordover. I Norge var nyhetsbildet preget av diskusjoner rundt mulige konsekvenser av et stort antall asylsøkere som særlig kom over Storskog i Finnmark. Etterhvert som antallet asylsøkere steg økte også temperaturen i en rekke debatter i offisielle- og sosiale medier.

Utgangspunktet for denne artikkelen var en undring i etterkant av en frivillig kunstdugnadsinnsats på asylmottak for flyktninger. Hvilke tanker og meninger hadde de frivillige om sin egen innsats? I

\footnotetext{
${ }^{1}$ Institutt for barnevern og sosialt arbeid. Universitetet i Troms $\varnothing$, Campus Harstad. E-mail: jon.arnesen@uit.no

${ }^{2}$ Universitetet i Tromsø, Campus Harstad \& Høgskolen i Oslo og Akershus. E-mail: rikke.gurgens@hioa.no
} 
artikkelen beskriver og fortolker vi et utvalg av disse kunstdidaktikernes skjønnsutøvelse og diskuterer hvordan denne skjønnsutøvelsen omsatt i en kunstpraksis kan inngå i utviklingen av det kulturelle demokrati.

\section{KunstInnsatsen i nord}

I oktober ble det tatt et initiativ av lokale kunstnere og kunstpedagoger til en kunst- og aktivitetsinnsats på et akutt opprettet asylmottak for familier og mindreårige asylsøkere i Nord-Norge. ${ }^{3}$ Prosjektet ble gitt navnet 'KunstInnsatsen'. Innsatsen hadde fokus på barn i grunnskolealder og at disse potensielt hadde erfaring fra krig og konflikt i Midtøsten. Barn i skolepliktig alder med midlertidig opphold i Norge har ikke skolerett. Først etter tre måneder i landet får barn skoletilbud i kommunen de oppholder seg i. KunstInnsatsen ble derfor innrettet mot venteperioden til 25 barn på mottaket med mål om å gjøre hverdagen mer meningsfull. Prosjektet tok utgangspunkt i at det å være på flukt representerer en mulig utrygghet, opplevelse av fortvilelse og tap av både eksistensielt og kulturelt fotfeste i tilværelsen. På dette bakteppet ble den aktivitetsbaserte KunstInnsatsen iscenesatt som et avgrenset prosjekt over 2 måneder. ${ }^{4}$ Initiativtakerne ville gi barna en fristund fylt med musiske opplevelser og erfaringer som kunne styrke troen på et mellommenneskelig møte på tvers av kulturer, identiteter og språk. Kunstnerne som deltok skulle tilrettelegge for ulike estetiske inntrykk og gi muligheter for uttrykk av tanker og følelser gjennom kunst, kunstrelatert lek og aktivitet for barn. Sammen med kunstnerne deltok også norske foreldre og barn i skolealder fra et geografisk avgrenset område rundt mottaket. Etterhvert viste det seg at KunstInnsats-møtene utviklet seg til å nå mange av asylantene ved mottaket, både enslige mindreårige og voksne, i tillegg til barna og deres foreldre. Akuttmottaket ble lagt ned i 2016 og alle asylsøkerne ble flyttet til andre mottak eller sendt ut av landet.

\section{Kunstdidaktikk for sårbare grupper}

Kunstintervensjoner brukes i emansipatorisk arbeid for sårbare mennesker i ulike krigs- og konfliktområder (Horghagen, 2012, Horghagen \& Josephsson, 2010). KunstInnsatsen skriver seg inn i denne fagtradisjonen der man anvender kunstfagene i en humanitær sammenheng for å skape en mer meningsfull tilværelse for deltakerne (Horghagen, 2016; Horghagen \& Josephsson, 2010). Prosjekter av denne art initieres både som forebyggende eller behandlende aktiviteter (Waaktaar \& Christie, 2008), som aktivisme eller som fredsskapende prosjekter, enten de er lokalisert direkte inni konfliktområdet eller i områder der flyktninger og asylsøkere søker tilflukt (Storsve \& Westbye, \& Ruud 2010). Også i Norge finner vi flere slike prosjekter der kunsten brukes som alternativ behandling av traumer. Et eksempel er Merete Roaldsnes' prosjekt som undersøker hva deltagelse i en musikkterapigruppe kan bety for ungdommer med bakgrunn som enslige mindreårige flyktninger (Roaldsnes, 2014).

Vi leser KunstInnsatsen inn i et internasjonalt perspektiv knyttet til fredsskapende og forebyggende arbeid der målet ofte er å gi lindring og positivt flytte fokus fra lidelse til tilstedeværelse gjennom en kunstdidaktisk prosess. «Action for Hope» i Libanon initierer anvendte kunstprosjekter i Qaa og i Shatila i Beirut. Lederen, Basma El Husseiny er selv fra Egypt og arbeider som kulturarbeider og aktivist i Midtøsten. Hennes engasjement begynte med et solidaritetsbes $\varnothing \mathrm{k}$ til en syrisk flyktningleir i Tyrkia. Der møtte hun mennesker på flukt fra Syria som var fremmedgjorte og traumatiserte av krig, vold og nød.

\footnotetext{
${ }^{3}$ En dramapedagog og en musiker samlet en bredt sammensatt gruppe mennesker med bakgrunn innen ulike estetiske fag, drama/teater, musikk, kunst \& håndverk til dugnadsinnsats. I den videre fremstillingen er disse gitt fellesbetegnelsen 'kunstnere'

${ }^{4}$ Innsatsen bestod av 1-2 bes $\varnothing \mathrm{k}$ pr uke i 2 november og desember, midt i mørketiden.
} 
Hun initierte i forlengelsen av dette besøket, Action for Hope, som et kunstdidaktisk prosjekt, fordi hun har sterk tro på kunstens verdi i tider med krig og uro. Kunstdidaktikeren El Husseiny forteller:

/.../ vi fikk også oppleve hva en gruppe på 17 kunstnere og kulturformidlere kunne gjøre for å hjelpe dem, bare i løpet av noen få dager. Det var nesten magisk: Unge gutter og jenter fikk tilbake gnisten i øynene etter noen få teater- eller sangklasser, mødre som tidligere hadde vært tause lo sammen med barna sine. Selv menn som var herdet av grusomheten de hadde vært vitne til, så på det som skjedde med tårevåte øyne (El Husseiny, 2016, s.1).

Action for Hope-prosjektet kan forstås som en reaksjon på 《/ ... /den undertrykte sorgen mennesker i nød bærer på, og er basert på kunstens unike evne til å skape en positiv kraft» (El Husseiny, 2016, s.1) Programmet er primært rettet mot flyktningsamfunnene i Libanon og Jordan, men utvides også mot Tyrkia og Irak. El Husseiny uttaler at: «Samfunn som rammes av krig, fattigdom eller naturkatastrofer, mister ikke bare hus, klær og penger, men også immaterielle verdier. De mister den sosiale veven som knytter dem sammen med andre: slektninger, naboer og venner» (El Husseiny, 2016, s.1).

Kunstfaglige reaksjoner på splittelse og konflikt kan ta mange former. Både i Betlehem og i Berlin ble visuell kunst tatt i bruk for å innta muren - stengselet som ble satt opp midt i nabolag og som splittet både familie og venner. Berlinmuren var $155 \mathrm{~km}$ lang og ble på vestlig side malt med spraybokser og pensler og dermed inntatt av offentligheten. Ennå i dag selges dekorekte biter av Berlinmuren til turister på gjennomreise. På Vestbredden er det også reist en mur. Den er blitt $438 \mathrm{~km}$ lang, og skal forlenges med ytterligere $362 \mathrm{~km}$ (UNRWA 2011).5 På muren er det malt bilder som en reaksjon på myndighetenes beslutning om å skille folk fra folk.

Det siste eksemplet på kunstfaglig emansipatorisk arbeid vi ønsker å trekke frem er prosjektet: «In Place of War» som ble initiert av den britiske professoren i anvendt teater, James Thompson, in 2004. Hans utgangspunkt var å forske på forholdet mellom performance og krig (Thompson, Hughes, Balfour, 2009). I dag, 12 år etter oppstarten drives In Place of War som et stort nettverk for:

/.../ artists and creative communities living in sites of war, revolution and conflict to build powerful networks create social change through creativity and demonstrate the value of the arts to public space, public life and public debate. Our work is spread across five core areas: digital networks, academic research, creative entrepreneurialism, creative spaces, and artistic production (http://www.inplaceofwar.net).

Denne organisasjonen knytter altså forskningsmiljøene til kunstproduksjon og kulturestetisk arbeid ute i feltet. ${ }^{6}$ Under et forskningsintervju ${ }^{7}$ med Thompson i 2011 uttalte han at hele feltet «Applied Theater» i UK har sitt utspring i universitetsmiljøene og har derfra bidratt ut i samfunnet med konkrete teaterprosjekter i fengsler, krigssoner, belastede bomiljøer o.l. (Gjærum, 2013).

Vi har nå sett tre ulike anvendte kunstprosjekter som har mennesker i krig og konflikt som sin målgruppe. Analyser av anvendte kunstprosjekter viser at marginalisere mennesker i krise gjennom kunsten kan få tillitt og trygghet, dele erfaringer, synliggjøre seg selv og sin kompetanse, organisere hverdagslivet på ny, erstatte eksistensielle kriser med eksistensiell mening og erfare respekt, forståelse

\footnotetext{
6 "Through our production work, we connect innovative grassroots artists from sites of conflict to new international audiences. We have worked on numerous projects bringing artists from Colombia, India, Nepal, Egypt, Brazil, Congo, Zimbabwe, and Venezuela to collaborate and perform with UK artists /.../ We have produced several international collaborative recording projects, 33RPM Voices of the Revolution and the Makakoba Project, which showcased undiscovered talent from some of the world's most disadvantaged communities." http://www.inplaceofwar.net/ ${ }^{7}$ Rikke Gürgens Gjærum intervjuet Thompson i forbindelse med artikkelen: Gjærum, Rikke Gürgens (2013). Applied theatre research: discourses in the field. European Scientific Journal. Vol. 3. http://www.eujournal.org/index.php/esj/article/view/2448
} 
og anerkjennelse (Horghagen, 2016, s. 120; Thompson, Hughes, \& Balfour, 2009; Storsve \& Westbye, \& Ruud 2010). Kunnskap om disse prosjektene lå i bunnen for organiseringen av KunstInnsatsen.

\section{Forskningsmetodiske betraktninger}

Denne artikkelen bygger på en forskningsstudie bestående av syv kvalitative forskningsintervju basert på et strategisk utvalg av aktørene i KunstInnsatsen. ${ }^{8}$ Utvalget ble gjort for å få innsikt fra helt ulike posisjoner; aktørperspektivet, arrangementsperspektivet, deltagerperspektivet, foreldreperspektivet og barneperspektivet. Studien består derfor av beretninger fra informanter med relativt ulike erfaringer fra feltene pedagogikk, kunst og kunstdidaktikk. Fortellingene de delte under intervjuene var knyttet til refleksjoner rundt deres egen innsats ved asylmottaket. En innsats som først og fremst var rettet mot barna, selv om aktørene på sine bes $\emptyset \mathrm{k}$ ved mottaket $\mathrm{i}$ varierende grad også møtte enslige unge og voksne. Studien er konstruert som et enkelt casedesign med flere analyseenheter, der den aktuelle forskningsstrategien er knyttet til en avgrenset gruppe (Johannessen,Tufte, \& Christoffersen, 2006; Ringdal, 2007, s. 291). Datainnsamlingen ble gjennomført to måneder etter prosjektslutt ved hjelp av halvstrukturerte kvalitative forskningsintervju og ved bruk av åpne spørsmål (Jacobsen, 2005; Thagaard, 2003).

Utgangspunkt for studien var en undring over hva en slik KunstInnsats igangsetter hos aktørene. Innholdet i intervjuene hadde derfor fokus på informantenes tanker om egen deltakelse i KunstInnsatsen, men også på deres forståelse av kunstdidaktiskarbeid generelt overfor sårbare mennesker som unge flyktninger.

Transkripsjonene av intervjuene ble fortolket og kategorisert i meningsbærende temaer (Jacobsen, 2005) på bakgrunn av formålet med studiet som handler om hvilken skjønnsutøvelse som ligger bak kunstdidaktikeres møte med et asylmottaks unge beboere. Tolkningsarbeidet ble gjennomført fra en åpen koding av de transkriberte intervjuene via en aksialkoding til en selektiv koding (Corbin \& Strauss, 2008). Fire tematikker utkrystalliserte seg: Roller og iscenesettelse, Demokrati og dannelse, Samspill som danning og Sanselig varensfornemmelse. Analysearbeidet, der funn diskuteres i lys av aktuelle og relevante teorier, har medført en dreining mot et mer fenomenologisk forskningsdesign. En slik dreining har bestått av å forstå mening med en kunstinnsats fortolket gjennom informantenes fortellinger om kroppslig erfaring, fornemmelse, blikk og refleksjon. Forskerens fortolkninger baserer seg i stor grad på teori hvor livsmestring står sentralt (Johannessen et al., 2006). I fortolkningsprosessen, der vi som forskere ønsket å gripe etter dypere mening i dataene, har vår intuisjon og forskningsmessige fagsensitivitet basert på tidligere erfaringer hatt avgjørende betydning. Fortolkningen vi gjorde representerer en form for «dobbel hermeneutikk» (Giddens, 1984, s. 284) hvor vi som forskere først fikk innblikk i aktørenes meninger, tanker og handlinger, og på dette grunnlaget deretter fortolket denne kontekstuelle virkelighet som grunnlag for videre å skape forståelse og mening. Vi arbeidet så analytisk med meningsdanning ved bruk av teori, og anvendte derfor fem ulike teoretiske forståelser av phronesis for å forstå dataene ytterligere (Hansen, 2008, s. 278). Teoretisk knytter vi analysene i diskusjonen til teori om emansipatorisk arbeid (Horghagen, 2012; Horghagen \& Josephsson 2010) og utvikling av et kulturelt demokrati (Engelstad, 2006).

\footnotetext{
${ }^{8}$ Jon Arnesen har bidratt til datainnsamling, intervju og analyse. Initiativtaker til prosjektet, Rikke Gürgens Gjærum, har bidratt som andreforfatter av teksten i sluttstillingen av artikkelens diskusjon.
} 


\section{Kunstens politikk}

En hverdag vil for de fleste mennesker kunne bestå av en rekke valg og handlinger av både estetisk og etisk art. For kunstneren er estetikken og etikken forbundet på en slik måte at de to sfærene utfordrer hverandre (Meyer, 2015). KunstInnsatsen innehar en estetisk dimensjon som ikke bare omfatter tradisjonelle kunstfag, men også bygger på en etisk fordring knyttet til møtet med mennesker i en marginalisert livsposisjon (Aure \& Gjærum, 2015; Gürgens, 2004). Utgangspunktet for artikkelen er et utvidet kulturbegrep og et hverdagsestetisk perspektiv hvor kunsten ikke skiller seg fra hverdagen, men oppstår i og som en del av denne (Hohr \& Pedersen, 1996). Estetikken er en erkjennelsessfære hvor menneske erfarer, foretar valg og skaper kulturestetiske uttrykk som inngår i nasjons- og samfunnsbygging (Arnesen, 2015a). KunstInnsatsen kan derfor forstås som en konkretisering og aktualisering av hverdagsestetiske handlinger som også har skjønnsmessige etiske implikasjoner. Samlet sett medfører en slik forståelse at en kan snakke om en kunstens politikk.

Ifølge den franske filosofen Jacques Rancière (2012b) er politikk uløselig knyttet til sansing, til fordeling av det sanselige og dermed også det estetiske. Rancière bruker betegnelsen det estetiske kunstregimet for å beskrive en sanselig væremåte, typisk for kunstproduktene, der kunstens gjenstander blir identifisert ut i fra tilhørighet i et bestemt regime av det sanselige (Rancière, 2012b, s. 28). Det estetiske og det politiske er derfor to sider av samme sak hvor begge arbeider med det som er mulig å sanse, erfare og uttrykke i fellesskap. På et grunnleggende nivå oppstår derfor politikk som en estetisk hendelse og et brudd på en samfunnsmessig orden og formidling eller distribuering av det sansbare. Dette får dermed også konsekvenser for hvem som er kvalifisert til å tale, til å høres og sees. Det vil si en etablert sansemessig konsensus som medfører at noen blir gitt, eller ikke gitt en posisjon eller stemme som gjør dem synlige i samfunnet. Konsekvensen er at enkelte blir favorisert, mens andre blir marginalisert (Rancière, 2012b).

For Rancière består politikk av det man ser og kan si noe om, men som også innebefatter uenighet eller interessekonflikt knyttet til det sanselige. Slik forstått vil et estetikkbegrep som omfatter mer enn bare kunsten, også inngå i systemet av sanselige selvfølgeligheter, av forutbestemte former som bestemmer hva som presenterer seg for sansing og opplevelse (Rancière, 2012b, s. 13). Ifølge Rancière må politikk bli forstått utover partipolitikk eller diskusjoner i samfunnet knyttet til makt og maktfordeling.

Rancière bruker begrepet politi for å beskrive alle institusjoner som sørger for en inndeling eller en telling som medfører at noen grupper blir favorisert, mens andre blir marginalisert. Det vil si et politi for opprettholdelse av det sanselige regime. En ekte politikk knytter Rancière til de diskurser og praksiser som sikter mot likhet og som konfronterer politiet når det ikke skjer (Rancière, 2004, s. 13). Flyktninger på et akutt asylmottak er i en marginalisert livssituasjon og en kan anta at flyktningbarn er i en end mer maktesløs, marginalisert og isolert eksistensiell situasjon hvor tilgang til det sanselige er begrenset, både gjennom geografisk plassering og mangel på ressurser utover det høyst nødvendige for å overleve.

Slik vi leser Rancière, kan KunstInnsatsen forstås som en inngripen gjennom en kunstens politikk i det estetiske systemet av sanselige selvfølgeligheter og dermed en synliggjøring av de usynlige (Rancière, 2012b). Denne inngripen skjer i form av en formidling og deling av det sansbare, ved musiske opplevelser, tilretteleggelse for estetiske inntrykk og uttrykk, kunstrelatert spontan lek og kulturestetiske kollektive aktiviteter. Denne formidlingen appellerer til livsglede, livsmot og mulighet for individuell mening. Det vil si noen grunnleggende forutsetninger for å være fullverdige medlemmer av et større felleskap eller samfunn. Eller sagt på en annen måte, KunstInnsatsen kan betraktes som en aktiv 
handling som starter når initiativtakerne setter spørsmåltegn ved motsetningen mellom å se og å handle, og som derfor også strukturerer forholdet mellom å se, å si, og å gjøre. En kunstner eller kunstdidaktiker kan i kunstkommunikasjonen gripe inn og endre fordelingen av posisjoner og sanselig tilgang, her overfor asylantene (Rancière, 2012a, s. 25). En slik innsats eller inngripen som kan endre eller forstyrre distribusjonen av det sansbare og derfor også bidra til en gjensidig emansipasjon mellom kunstnerne/didaktikerne og asylsøkerne. Denne frigjøringsprosessen begynner med andre ord når kunstneren/kunstdidaktikeren forstår og makter å forholde seg til en marginalisert gruppe gjennom handling på en slik måte at han/hun bekrefter og forandrer fordeling av posisjoner og dermed forskyver fordelingen av det sanselige.

\section{Kunnskap og handling}

Hvorfor vi handler som vi gjør er et hovedspørsmål som behandles av Aristoteles i Den Nikomakiske etikk (Kroksmark, 2006, s. 57). Våre handlinger hanger sammen med vårt kunnskapsgrunnlag og til hvordan kunnskapen konstrueres og anvendes. Tre kunnskapsbegrep er i denne forbindelse sentrale: episteme, techne og phronesis (Aristoteles, 1999). Techne er den håndverksmessige kunnen, episteme den tradisjonelle vitenskapelige og boklærde viten mens phronesis er den praktiske visdom, forstått som sanselig klokskap eller fornuft (Aristoteles, 1999, s. 60). Disse tre utgjør til sammen den aristoteliske epistemologi (Johannessen, 1984, s. 122). For Aristoteles er phronesis knyttet til en besindighet bak våre handlinger som bevarer vår klokskap og gjør oss til handlekraftige og velreflekterte mennesker med kløkt og praktisk visdom. Aristoteles hevder at denne klokskapen er en holdning som kan frembringe menneskelige goder oppnådd gjennom handling (Aristoteles, 1999, s. 62). Med bakgrunn i Den Nikomakiske etikk videreutvikler den danske filosofen Finn Torbjørn Hansen fem forståelser av phronesisbegrepet som vi ser som aktuelle og relevante i diskusjonen av dataene fra KunstInnsatsen (Hansen, 2008, s. 279).

\section{Diskusjon}

Vi vil nå analysere informantenes skjønnsutøvelse og diskutere hvordan denne skjønnsutøvelsen omsatt i kunstpraksis kan inngå i utviklingen av det kulturelle demokrati. I møte med flytninger kan en som kunstner og kunstdidaktiker kjenne seg maktesløs, men likevel kjenne på en fordring til handling: «Mange kan gjøre en bitte liten innsats som sammen blir en stor innsats / ... / målet vårt var at vi både skulle vise noe og bidra med noe» (Informant 1) ${ }^{9}$. Dette målet med selve KunstInnsatsen kan defineres som phronesis, altså det som gjør mennesket i stand til å gjøre det som er godt og tjenlig, ikke som enkelttilfelle, men i forhold til det gode liv generelt. Denne kløkt eller dette skjønn, forstått som praktisk visdom, er knyttet til mennesket som handler i en foranderlig verden. Skjønnet utfordres eller bringes i spill når mennesket står i en situasjon av valg, og hvor valg er preget av tvil. En står med andre ord i det åpne og skal handle i en situasjon preget av usikkerhet. Da har en valgmuligheter og må foreta valg som ikke uten videre kan forankres i prinsipper, men i åpen undring (Hansen, 2008). Vi som forskere og kunstdidaktikere har undret oss, og på bakgrunn av denne undringen vil vi presentere informantenes fortellinger sett gjennom fire tematikker: Roller og iscenesettelse, Demokrati og dannelse, Samspill som danning og Sanselig varensfornemmelse.

\footnotetext{
${ }^{9}$ I det følgende er muntlige sitat fra informantene angitt med et tall i parentes for å skille informantene.
} 


\section{Roller og iscenesettelse}

Informantenes tanker og refleksjoner om roller og iscenesettelse av KunstInnsatsen er tydeligst $\mathrm{i}$ en innledende fase, men oppstår også i forbindelse med praktiske og didaktiske utfordringer som dukker opp undervis. Organisering av KunstInnsatsen krevde en detaljert utarbeidet arbeids- og tidsplan og en klar bestilling som ramme for innholdet, men også en backup-plan ved frafall. I denne planen ble aktørene tildelt hvert sitt møtetidspunkt og rolle, som ga en åpen ramme for iscenesettelsen av de kunstdidaktiske tiltakene. Noen av informantene så for seg hvordan de kollektivt kunne «løfte», mens andre ikke umiddelbart visste helt i hva eget bidrag kunne være. Det å bli spurt om å innta en rolle som kunstdidaktiker på et asylmottak ble av enkelte oppfattet som en tillitserklæring, selv om de var usikre i starten om hva de kunne bidra med.

En informant uttrykker at: «Jeg vet at initiativtakeren har tro på meg og da sier jeg ja uansett!», mens en annen informant uttaler at vedkommende deltok i KunstInnsatsen $« / .$. / fordi jeg hadde lyst til å gi disse et ok møte med Norge» (5). En tredje informant forteller om beveggrunnen til sin deltagelse at: «Jeg har tro på at når de ser en slik inngang til det å være sammen, så får de større tillit til oss, og vi får større tillit til dem»(1). Vi ser her hvordan informantenes fortellinger knyttet til KunstInnsatsen gjennomgående er preget av gjensidig respekt og tillit, men også av undring, noe som på mange måter er en grunnforutsetning for samspill mellom mennesker. Informantenes fortellinger innehar også en nerve eller sårbarhet. Det kan henge sammen med at tillitsgiver stiller seg i en mer sårbar situasjon enn tillitsmottaker på grunn av muligheten for avvisning. Som tillitsmottaker står barn i en særstilling, fordi de i så stor grad er avhengig av de voksnes tillit (Grimen, 2009, s. 60). Vi vet at en grunnleggende gjensidig anerkjennelse av den andre kan oppfattes som en forutsetning for et inkluderende samspill og kommunikasjon, slik informanten (1) legger til grunn for sine valg. Etikkforskeren Odin Lysaker (2011) argumenterer, med støtte i Honneth og Hegel, for en implisitt anerkjennelse som en forutsetning for et universelt menneskeverd. I den inngår tre anerkjennelsesformer ${ }^{10}$. Den første er kjærlighet, som er primær og innenfor en persons intimsfære, den andre er rettighet, som er knyttet til respekt i en gjensidig relasjon og den tredje er solidaritet som kan knyttes til verdsettelse som en ressurs i vid forstand (Lysaker, 2011). Flere av aktørene tenkte også grundig gjennom hvordan de ville opptre eller fremstå i møte med asylsøkende barn og familier på flukt for å forsøke å legge et grunnlag for samspill og kommunikasjon:

Første gang dro vi som en familie og hadde med barna, jeg skulle stille der som mamma og ikke dra dit som [tittel]. Ja, fordi min [yrkesrolle og tittel] skaper ingen kommunikasjon og det betyr ingenting for dem hva du kommer som, annet enn at du virker trygg. Det gjorde jeg bevisst for å få kontakt med mødrene, hvis de ser at du er en mamma så åpner kommunikasjonen på en helt annen måte enn med mennene, kanskje? (1)

Et første møte mellom mennesker innehar en spenning slik informanten uttrykker det her. Det oppstår en forventningsnivellering i møtet, selv om en på forhånd har tenkt nøye gjennom rollen og det en ønsker å dele. Musikk innehar en særegen mulighet for kontakt og samspill uavhengig språk og kulturelle forskjeller. En av informantene fortalte at: «Jeg hadde lest i avisen, gjort meg mine tanker - hvordan har de det egentlig - er litt nysgjerrig. Jeg har ofte spilt på mange rare anledninger, og det har fungert det (4). En annen informant meddelte at han brukte en blanding av:

/.../ musikalsk opplevelse med instrumentet mitt, spilte for dem og engasjerte dem med sanger som de kunne være med på. / .../ Tenkte jo å spille for barna, men det viste seg at vi kunne spille for alle (3).

\footnotetext{
${ }^{10}$ Som stammer fra Hegels Jena-skrifter.
} 
Vi ser her at en litt usikker nysgjerrighet hos informantene utvikles til en tryggere kunstneridentitet ute i det anvendte feltet. Flere informanter utrykker en slik innledende usikkerhet. De forteller om tvil om hvorvidt egen kunstfaglig kompetanse vil komme til å fungere for asylsøkende barn. En formidler tvilen rundt starten:

/.../ Hva skal en gjøre, hva kan fungere? Dette vet jeg vel egentlig ikke noe om, kanskje ikke kapabel /.../ ingen kompetanse innenfor slikt flyktningarbeid eller pedagogikk, men, spent og litt skummelt (4).

Vi ser informanten tviler, men han har likevel en tro på egne fagkrefter, det er det anvendte perspektivet han tviler på fordi han mangler erfaring fra sosialpedagogisk kunstarbeid. Krüger og Strandbu (2015) og flere forskere med dem, hevder at musikk kan føre mennesker sammen, slik at vennskap og sosiale bånd kan knyttes, spesielt i en tid hvor musikk er «allestedværende» (Krüger \& Strandbu, 2015). På den første KunstInnsatsen etter en innledende oppvarmingsrunde ble Krüger og Strandbu's funn bekreftet i rommet da en av de mannlige asylantene, med røtter i Midtøsten, reiste seg entusiastisk opp og spontant danset til allmenn jubel, noe som løftet stemningen i rommet, forteller informantene.

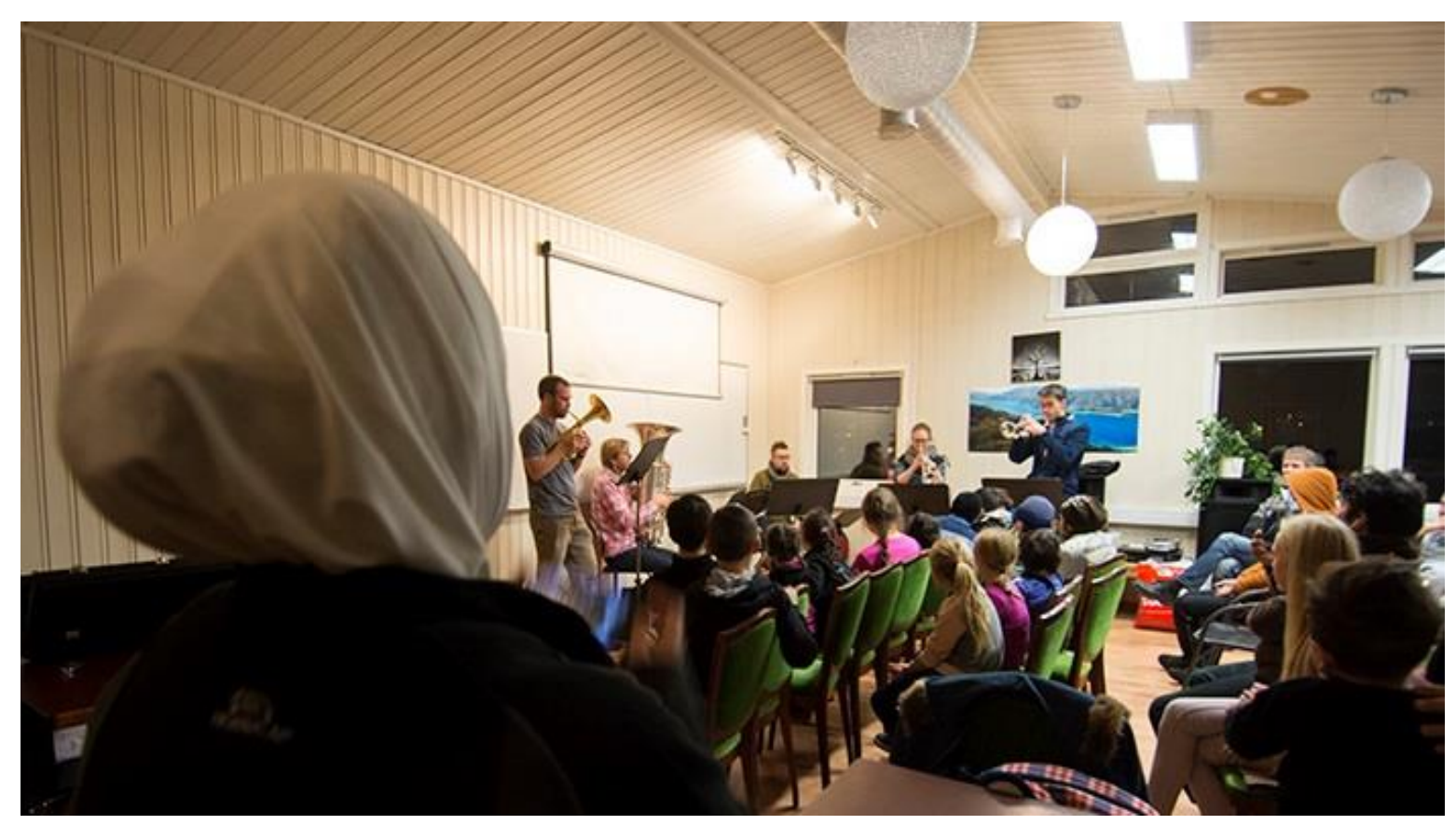

Fra første KunstInnsats. Foto: Kjetil Nilsen.

Flere av asylsøkerne tok bilder og formidlet disse i sosiale medier mens kunstaktivitetene pågikk. Flere av informantene formidlet at de bar med seg ulike «fordommer» mot asylsøkere som ikke var basert på egne erfaringer med flyktninger.:

/.../ leser i avisen, en hel haug med flyktninger, man skaper bilder $\mathrm{i}$ hodet av negativ art, at de er så fremmede og da vet jo jeg ikke hva jeg kan bidra med - for jeg er jo bare meg. Så viste det seg jo, at det var tåpelige tanker. Men det var en følelse jeg fikk (3).

Flere av informantene uttrykte på samme måte at de på forhånd var usikre på hvordan de skulle kunne formidle noe i møte med et titalls forskjellige språk og kulturer $(1,3,4,5,7)$. Men når språket ikke strakk til, så tok de kroppsspråk i bruk, slik denne informanten forteller om: 
/ ... / det kaotiske med mange forskjellige språk og å oversette var jo ikke lett, og etter hvert ga vi vel bare opp å oversette og snakket norsk og pekte og forflyttet folk. Stilte opp og flyttet på stoler og gjorde ting i et mønster som barna og de voksne forsto (1).

Mens det musikalske språket ikke kjenner kulturelle og språklige grenser så øker utfordringene og kompleksiteten når en skal samspille med verbalt språk. Flere informanter valgte derfor tegning og sang når de skulle kommunisere med barna:

Begynte med bli-kjent sanger med bevegelse, så dramatiserte ungene eventyret [Bukkene bruse]. Ungene, fikk rytmeinstrument for å være med å bygge opp og støtte handlingen. De var kjempeflinke, det fungerte godt. / ... / så delte vi i grupper, tegnet fra eventyret, hadde tegnet litt først og skrevet noen navn, bru eksempel (6).

Eventyr med et universelt tema, dramatisering og sanglek ved hjelp av rytmeinstrumenter var én innfallsvinkel som ble brukt når KunstInnsatsen skulle etablere samspill og kommunikasjon. En annen informant trakk frem at: «En må møtes og få kunnskap om hverandre gjennom kulturaktivitet, for det kan være samlende» (5). Og nettopp den samlende effekten av KunstInnsatsen må sies å være et klart funn, fordi beboerne på asylmottaket i utgangspunktet ikke hadde noe samlingspunkt før KunstInnsatsen kom. Men gjennom workshopene ble det etter hvert utviklet en tradisjon på mottaket for å samles. En informant var særlig opptatt av å skape en brobyggende kultur som samling mellom folk på et sted:

Musikk er kultur, den er uten ord og alle forstår den på sitt vis. Den er brobyggende, den skaper ikke konflikter. Kunsten har den evnen at den kan løfte deg ut av en hverdag. Det er viktig for alle, for de [asylsøkerne] mer nødvendig, det var et ønske om å komme ut av den situasjonen de står i nå (4).

Prosjektet viser at det ikke er lett å gå inn i rollen som kunstdidaktiker, sette rammer og skape grenser for både lytting og engasjement med barn og unge i en midlertidig asylkontekst:

Utfordringen ble å sette noen rammer, men vi rakk ikke det før det var i gang. De uttrykte ren lekelyst og det var mere kaotisk enn det jeg hadde opplevd i store grupper før /.../ de hadde også en iboende energi, og når den åpnes går det fort i svingene. Etter en stressa lang reise, og en virkelighet hvor en ikke vet hvor lenge ting varer - muligheten til å gjøre slike ting, så er en skrubbsulten på aktivitet, og vil få gjort så mye som mulig /.../ så egentlig mistet jeg kontrollen i løpet av 30 sekunder, tror jeg. Jeg ble veldig frustrert /.../ Det var en utrolig kaotisk situasjon fordi det var barn overalt og maling overalt/ ... / Barna hadde det nok gøy, men for meg som profesjonell var det en fiasko, jeg var nesten traumatisert etterpå /.../ En neste gang, da vil jeg tenke mer igjennom grupper og delinger, mindre grupper. Det ble altfor mange (5).

Informantene forteller altså om en viss frustrasjon i etterkant over å ikke å mestre de planlagte aktivitetene. Et første møte med en gruppe barn var i de fleste tilfellene utfordrende i forhold til å finne et grunnlag å samarbeide og kommunisere ut fra. I tillegg er det sannsynliggjort, gjennom informantenes fortellinger, at barn på flukt er bærere av erfaringer og opplevelser som kan øke disse utfordringene. Barn og unge i mottak er i en spesielt marginalisert sitasjon. Paulsen, Berg, \& Michelsen (2015) viser at disse har flere psykososiale problemer enn andre unge, og en stor andel asylsøkende barn er bærere av traumer som påvirker deres helse. Disse kan komme til uttrykk som konsentrasjons- og samspillsvansker. En følelse av å ikke nå helt frem hos en kunstpedagog i henhold til planen, kan likevel for et barn innebære en mulighet for å unngå sosial isolasjon og gi mulighet for lek. Tilretteleggelse for skapende kunst kan være viktig og vil kunne gi en positiv mulighet for en lekpreget skapende aktivitet som muliggjør at vanskelige følelser og vonde opplevelser kan uttrykkes gjennom en form. Spesielt siden både lek og kunst ansees å være et midler for å bearbeide og mestre livshendelser for barn og bygge bro mellom en indre forestillingsverden med en ytre virkelighet (Minde, 2000; Vedeler, 1999; Winnicott, 2003; Ødegaard, 2003). 
Vi tolker informantenes fortellinger om KunstInnsatsen slik at de tar i bruk både techne- og episteme-kunnskap som grunnlag for sine skjønnsmessige vurderinger og handlinger i møte med asylsøkende barn. Dette kaller filosofen Finn Torbjørn Hansen 'den pragmatisk- funksjonelle phronesis tilgang' (Hansen, 2008, s. 279) Det vil si at en har innebygd en rekke reflekterte tanke- og handlingsmønster langt utover det rent løsningsorienterte. Med andre ord, den løsningsorienterte skjønnsutøvelsen ser altså ikke ut til å opptre isolert, men ledes lett over i andre tanker og handlinger, og beveges til et nytt refleksjonsnivå. Det vil si at vi i datamateriale ser spor av en kontinuerlig bevegelse hos informantene hvor de beveger seg mellom flere phronesis- nivåer og stadier i det kunstdidaktiske arbeidet.

\section{Demokrati og dannelse}

I fortellingene til mange av KunstInnsatsens informanter uttrykkes flere tanker og skjønnsvurderinger som kan knyttes til dannelse gjennom tillitt og demokratiske verdier:

/.../ så får de større tillit til oss, og vi får større tillit til de. Jeg tenker at i samfunnet er det nok bra (1). Som borger i Norge, så har jeg tro på at vi skal ha kunnskap om hverandres kultur. Viktig å få til et møte fordi jeg var interessert i å få til et møte med disse nyankomne flyktningene. /.../En må møtes å få kunnskap om hverandre, gjennom kulturaktivitet og aktivitet. Det kan være samlende (5).

Informantene uttrykker her skjønnsvurderinger der det er forbindelse mellom tillit og medmenneskelighet, noe som gir erfaringer av samhold og fornyet felleskap. Videre forteller informantene at KunstInnsatsen fungerer slik at asylantene:

/.../ får litt annet å tenke på, andre impulser at det skulle skje noe i hverdagen der (asylmottaket) /.../ Barn som har havnet i denne situasjonen, og slik samfunnet møter dem /.../ og så går de med den usikkerheten i seg (6). /.../Veldig tro på at det å jobbe med kunst i forhold til flyktninger er viktig fordi at man har et felles språk. Og at man gjennom kunsten kan vise en medmenneskelighet, uten å love noe (1).

Det kan se ut som at det å inneha og utvise høy sosial tillit i det kunstdidaktiske møtet nærmest er en nødvendig forutsetning for en god KunstInnsats. Vår studie kan ses i forhold til den tverrkulturelle tillitsstudien til Jan Delhey og Kenneth Newton. ${ }^{11}$ De påviser i Tyskland, Ungarn, Slovenia, Sør Korea, Spania og Sveits mellom 1999 og 2001, høy sosial tillit hos mennesker som tror at det er få alvorlige sosiale konflikter og hvor følelsen av offentlig sikkerhet er høy, noe også våre informantene uttrykker. Videre finner Delhey og Newton at uformelle sosiale nettverk er forbundet med tillit, og at de som opplever å lykkes i livet er mer tilbøyelige til å uttrykke tillit (Delhey \& Newton, 2003). Informantene våre er etablerte kunstnere og kunstdidaktikere og kan dermed sies å ha lykkes i sine liv, de er åpne for KunstInnsatsen og de utvikler altså tillitt og medmenneskelighet overfor asylantene de blir kjent med i prosjektet. Informantenes fortellinger om at «man har et felles språk» som fører til at man får «kjennskap til hverandres kultur» og dermed utvikler en gjensidig tillitt, kan knyttes til en forståelse av betydningen av å være i verden, og at de dermed opplever at KunstInnsatsen påvirker deres egen værende. Vi fortolker dette som en eksistensialistisk erkjennelse knyttet til at du er dine valg (Hansen, 2008). Vi taler da om kunst som selvdannelse og verdiskaping hvor det en deler og formidler virker gjensidig utviklende og frigjørende. En kan anta at dette er grunnleggende og sentralt både for individuell dannelse og for et levende demokrati (Engelstad, 2006). Flere av informantene uttrykker forbauselse over hvor

\footnotetext{
${ }^{11}$ Newton er professor i sammenliknende politikk og Delhey er sosiolog.
} 
skolemotiverte de asylsøkende barna var på eget initiativ, fordi tradisjonell undervisning i språk i utgangspunktet ikke var en av målsettingene med KunstInnsatsen. Likevel var det sånn at:

/ ... / de unge enslige asylsøkeren og barna ville lære norsk. Tankene jeg gjorde meg etterpå var at du må ha et system! ̊ sitte og vente, vente lenge, før samfunnet kan ta deg inn ... formelt, sånn er det jo, men de må vente for lenge, tre måneder er for lenge uten at det skjer noe. Derfor er KunstInnsatsen så viktig. (6)

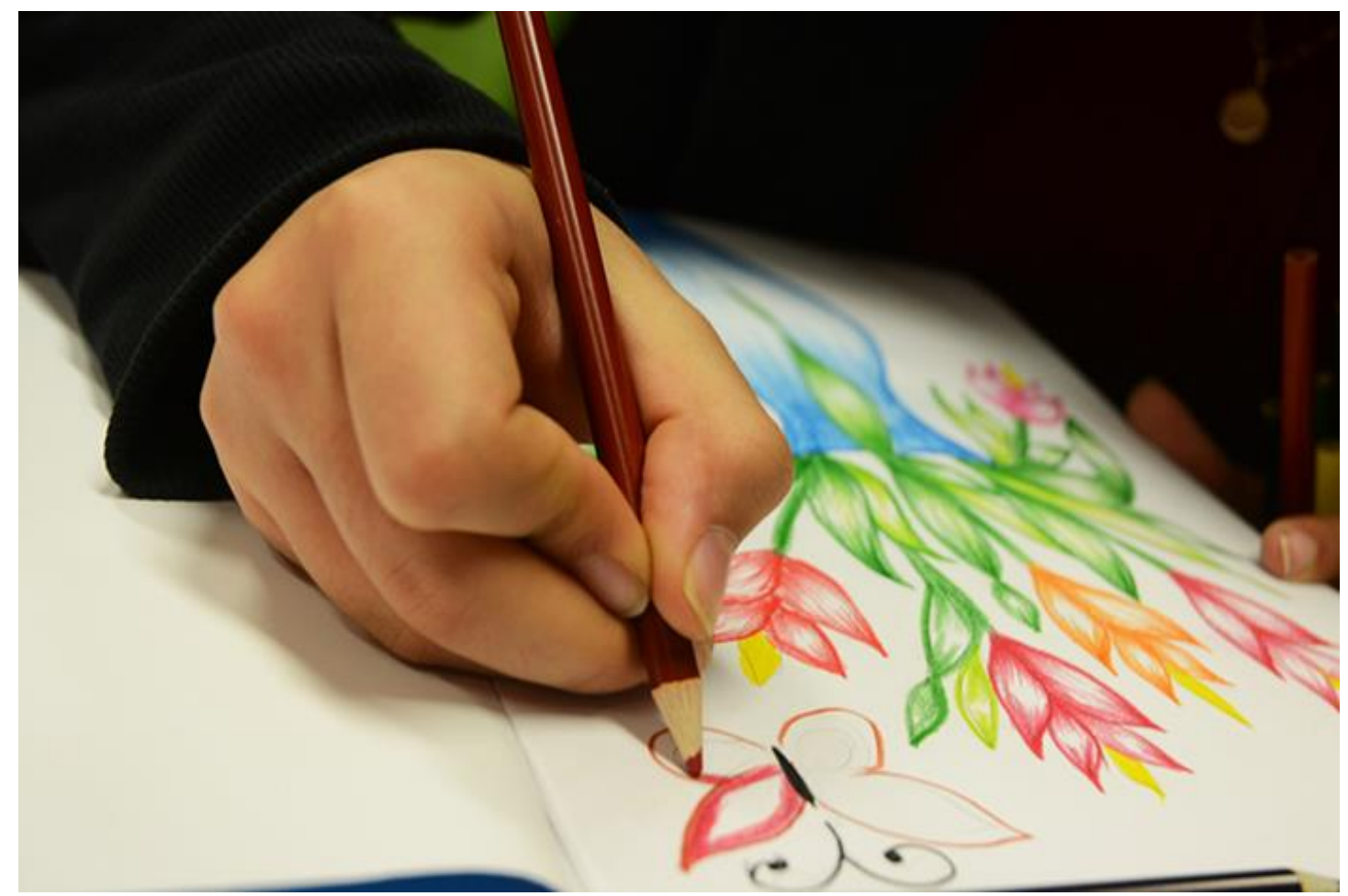

«Og så fikk ungene ei tegnebok, sett med fargeblyanter og skrivesaker som 'våre' barn delte ut, de hadde ikke så mye».

Foto: Kjetil Nilsen

Begrepslæring i norskfaget var ikke et mål i KunstInnsatsen, men et hjelpemiddel i de estetiske prosessene. En av informantene fortalte at barna hungret etter å lære:

/.../ enkle dagligdagse norske begrep. Der var de utrolig helt kjempeinteressert og aktive, og spurte om vi kunne komme tilbake å ha norskundervisning. Noen hadde allerede lært seg noe via YouTube. Vi hadde også med en språklærer [arabisk], og som oversette eventyret til arabisk. De var interessert, men det som fanget størst interesse var språket [norsk]. / ... / Det var kjempeviktig for dem [barna]. En av de voksne fortalte om de enslige unge guttene at de var fryktelig interessert - hvordan få lært oss dette fortest mulig, få hjelp [til å lære norsk] (6).

Når flere av informantene uttrykker forbauselse over barnas skolemotivasjon kan det handle om flere forhold. For det første kan det forstås som et møte med en fordom eller en stereotypi knyttet til asylsøkende barn og representerer derfor en mulighet til realitetskorrigering. For det andre kan det forstås som en refleksjon over betydningen av at barn får søke mening selv i et liv preget av usikkerhet og venting. I en kunstpedagogisk sammenheng, som i KunstInnsatsen, ser vi at det er viktig å møte barns behov for å gi uttrykk for tanker og følelser. Det er da man kan bidra til å utvikle deres uttrykkskompetanse fordi den estetiske skapelsesprosessen er en selvbekreftende prosess som er lettere å foreholde seg til enn en innestengt eller reaktiv handling (Ross, 1978). Gjennom prosessen utvikler 
barna sin følelsesintelligens (Ross, 1984). Deltagelse i estetiske skapelsesprosesser, som å spille, skrive eller tegne, kan betraktes som en kontinuerlig selvfornyende prosess knyttet til å gi livet personlig mening (Arnesen, 2015b). Samtidig er anerkjennelsen av et barneperspektiv også en anerkjennelse av den andre, og dens behov for vekst og utvikling i et samfunn, selv om det for de asylsøkende var uvisst hvilken fremtidig samfunnsmessig tilknytning de ville få. Å bidra til å lære asylsøkende barn norsk, fordi de etterspør det, er altså svært viktig, slik informantene forteller om. For tilegnelse av kunnskap er på sikt en vesentlig faktor for deltakelse i et demokratisk samfunn, samtidig som kunnskap i seg selv også representerer tilgang til makt. Estetiske fag kan dermed være med på å utvikle både individuelle og kollektive identiteter, noe som jo er en forutsetning for et fungerende demokrati (Engelstad, 2006, s. 63). Samtidig kan fagene bidra til en mulighet for å komme ut av skyggen og bli synliggjort som et likeverdig individ.

En av informantene sa overrasket at: «Ungene var veldig like våre barn, selv om mine fordommer før gjorde at jeg trodde at de skulle være mere inneslutta og bære på masse tungt. Aktive smilende barn, de var likere enn jeg hadde trodd» (7).

\section{Samspill som danning}

Informantene forteller videre om samspill og om hvor sårbart et verbalt samspill kan fremstå i KunstInnsatsen, selv om det kunstfaglige samspillet står i fokus i møtet mellom musiske mennesker (Bjørkvold, 1992; Gürgens, 2004). Formidling, deling og samspill forutsetter på mange måter et felles språk. Flere av informantene ga uttrykk for usikkerhet i mangel på et felles verbalt språk og prøvde å forberede seg ulike måter. En av KunstInnsats-aktørene prøvde å lære seg en del arabisk, for å få til et godt samspill siden dette var ett fellesspråk mellom flere av asylsøkerne.

Jeg gjorde i forkant en god del praktisk for å forberede meg. Kjente noen gutter fra Syria, fikk de til å hjelpe meg å lære noen arabiske ord, med de redskapene vi skulle bruke for å lette kommunikasjonsutfordringen (5).

En annen informant ville forberede seg ved å kunne synge Fader Jakob på arabisk:

Vi hadde jo også forventninger om at Fader Jacob på arabiske ville slå an, men det var jo norsk de ville ha. Og de ville lære, og de hadde lært mere norsk enn vi trodde også. De var også veldig interessert i det norske, noe vi ikke visste på forhånd. Vi tenkte deres arena, synge på deres språk, at vi skulle møte dem, men så ville de jo bare møte oss. Der lever de altså helt avsondret fra vår kultur også kommer vi dit, da vil de møte oss (3).

Slik vi leser beretningen til informanten kan dette møtet ha karakter både av en innvielse i en flyktningetilværelse, men også en differens, altså en åpenhet for forskjellighet. En slik dissens gir mulighet for ulike synspunkter og sprik i møte med dette flerkulturelle. Gjennom møter med ulike kulturer og miljøer får mennesker en mulighet til å utvikle egne kriterier for sitt liv og sin livsverden (Jerlang \& Jerlang, 1996). Denne prosessen kan defineres som dannelse, altså hvordan mennesket formes. (Løvlie, 2003). Asylbarnas klare forventninger om å lare representerer, slik vi ser det, en evne til selvdannelse og selvforvaltning. Flere informanter meningsbærer i sine fortellinger at de asylsøkende barna de møtte så ut til å være mere motivert for en integrasjonsprosess enn det informantene hadde forventninger om. Vi kan i den forbindelsen se KunstInnsatsen som en inngripen i fordelingen av det sanselige, noe som muliggjør dannelsen av nye felleskap (Rancière, 2012b). Kunsten blir da en måte å innta et sted på, et møte med et nytt felleskap hvor en deler og omfordeler det sanselige (Rancière, 2008, s. 536). Det muliggjør både ny kunnskap og nye erfaringer for alle deltagerne. En informant delte under intervjuet nyvunnen viten i sitt liv: «Man tror at man i utgangspunktet er dem overlegne. Og så forløses 
dette og man smelter sammen i en slags ny enhet som overrasket mange. Et gjensidig utbytte. Håper det kan lede til noe mer» (2). Vi ser her at informanten omtaler egne fordommer som blir gjort til skamme. Det er i den forbindelse interessant å se hvordan Øyvind Dahl, professor i kulturkunnskap, skiller mellom fordommer og stereotypier. Stereotypier forstås som tro, antakelser eller generaliseringer om en sosial gruppe som har enkelte fellestrekk. Men disse kan sette seg fast og vise motstand mot forandring og kan bli selvoppfyllende profetier. Dahl hevder at vi trenger disse for å mestre en kompleks verden (Dahl, 2013). Men dersom stereotypiene stivner og ikke er åpne for endringer, selv etter at ny kunnskap er ervervet snakker han om en fordom (Dahl, 2013, s. 69). Mens stereotypier er en oppfatning som hele tiden kan modifiseres, er fordommer en holdning som motsetter seg åpenhet for endringer (Dahl, 2013). Det er uklart om informantene skiller mellom sine erfaringer på denne måten, men de tilkjennegir samlet en åpenhet for endring etter KunstInnsatsen, og det ser ut til at møtene med asylsøkerne var en tilstrekkelig sterk ny erfaring til at dette ga en forandring eller en avkreftelse av egen fordom. En informant er tydelig i sine synspunkter i forhold til egne fordommer:

Våre fordommer blokkerer, men det er ikke noe en helt kan forstå på forhånd, noe en må forstå underveis. En kan ikke vite alt på forhånd. Vi tok og justerte og improvisere 'konserten' underveis. / . . / Det sterkeste, det viktigste er å erkjenne å se at, det er så selvsagt, 'folk er folk'. Barn er barn uansett hvor de kommer fra, det er bare et møte mellom folk det handler om, ikke om de er fra Syria eller Pakistan. Forventninger på forhånd, at det er fremmed, de har historier som jeg ikke kan foreholde meg til, 'derfor kan jeg ikke gi noe’, altså en masse rare tanker som i utgangspunktet skaper avstand (3).

Informanten konkluderer med at: «KunstInnsatsen er en positiv måte å møte sine fordommer på» (3). En informant trekker frem egeninteresse og nysgjerrighet: «Fokuserte på ungene, tenkte det var godt både for oss og for dem» (4). Samlet sett uttrykker flere av informantene at KunstInnsatsen muliggjorde et møte med egne fordommer og en personlig kritisk tolkning og ny-forståelse. Sett i et performativt kunstdidaktikkperspektiv kan man betrakte informantenes relasjonelle kunstutøvelse som en improvisatorisk og dramaturgisk performativ tilpasning av språk, planlegging og metodikk i møte med den konteksten, den kulturen og de menneskene de møter (Aure, 2013; Aure \& Gjærum, 2015). De personlige emansipatoriske endringene informantene forteller om kan ses som resultat av en sanselig inngripen, en KunstInnsats, og kan da forstås som en 'ekte politikk' hvor det siktes mot gjensidig likhet (Rancière, 2004). Politikk innebefatter uenighet eller interessekonflikt knyttet til det sanselige, ifølge Rancière. Informantene tilkjennegir at møte med asylsøkerne har vært interessant og lærerikt og at det kunstdidaktiske møtet forskjøv makt og hierarki i kommunikasjonen. En kunstens politikk for Rancière er nettopp knyttet til makt og maktfordeling slik den formidles og uttrykkes i samfunnet. Rancière bruker i tillegg begrepet politi for å beskrive alle institusjoner som sørger for en inndeling eller en telling som medfører at noen grupper blir favorisert, mens andre blir marginalisert. Det vil si et politi for opprettholdelse av det sanselig regime (Rancière, 2004). KunstInnsatsen kan forstås som en motmakt til det Rancirèrske politi, fordi det å gripe inn i den sanselige fordeling medfører at en vil forsøke å styre, kontrollere meningsdannerenes vinkling og blikk. Så mens politiet i Rancirèrsk forstand bidrar til begrensing eller lukking av tilgangen til det sanselig, fremstår KunstInnsatsen, ifølge flere av informantene, som en tydelig åpnende og bevegende kraft.

\section{Oppsummerende refleksjoner}

Utgangspunktet for artikkelen var en åpen undring over hva en frivillig kunstdugnadsinnsats kan igangsette hos de involverte partene. Vi har nå vist hvordan skjønnsutøvelsen omsatt i en kunstpraksis kommer til uttrykk i intervjuene av informantene. Informantenes uttalelser knytter KunstInnsatsen til 
utviklingen av det kulturelle demokrati på bakgrunn av deres kunstdidaktiske erfaringer med roller, iscenesettelse, dannelse og samspill.

Samlet sett formidler informantene i KunstInnsatsen skjønnsutfordringer knyttet til en kritisk handle- og dømmekraft som gir dem mulighet for personlig vekst gjennom en utfordring av egne fordommer og stereotypier. Slik sett bruker informantene en postmoderne og innovativ tilgang til feltet med en åpenhet og oppfinnsomhet overfor nye utsagn og hendelser. Det ser ut til å gi aktørene mulighet for vekst, eller dannelse, som bidrar til økt autonomi og kritisk bevissthet, særlig i forhold til den tidsaktuelle humanitære utfordring, som mennesker i Europa for tiden opplever i møte med asylsøkere på flukt fra krig. En personlig legitimitet i KunstInnsatsen som informantene uttrykker, bygger på en evne til å skape nye spørsmål. Skjønnsutøvelsen blir da et hjelpemiddel for informantenes dømmekraft som de utøver uten å kunne forankre dette i teoretiske kriterier. En forutsetning for dette ser for informantene ut til å omfatte en følsomhet og lydhørhet for de små unike fortellingene i bestemte konkrete situasjoner.

Slik vi tolker informantene kan KunstInnsatsen også leses som utøvelse av et kritisk-emansipatorisk skjønn og har derfor en parallellitet i Rancières forståelse av utøvelse av en 'ekte politikk' (Rancière, 2012b). Vi taler da om en utøvelse som innbefatter et kritisk ståsted, men med mulighet for emansipasjon og likhet i fordelingen av det sanselige. Det medfører at kunsten blir en måte å innta et sted på, slik som her på et asylmottak. I denne dannelsesprosessen erfarte informantene at relasjoner mellom mennesker, uttrykk, aktivitet, rom og tid ble omfordelt. Det innbar altså en forflytning for asylsøkerne fra å være rene tilskuere til også å bli deltakere i aktivitetene, og motsatt for kunstnerne/kunstdidaktikerne når asylsøkerne etterhvert ble aktivt deltagende og tok styringen, slik at informantene ble tilskuerne.

KunstInnsatsen ser derfor ut til å kunne bidra til en ny inndeling av det materielle og symbolske, og til å fordele sanselighet også til asylsøkende flyktninger. KunstInnsatsens omfordeling ser altså ut til å omfatte identiteter og posisjoner. En informant fortalte om opplevelsen av når den asylsøkende får en identitet og når 'deres' barn blir lik 'våre' barn, som f.eks. når den asylsøkende kvinnen med hijab blir fotograf, og når den asylsøkende muslimske mannen blir en far som leker med sine barn. Vi ser at informantene i medskapelsen av det kulturelle demokrati tar i bruk både techne og episteme som grunnlag for sine skjønnsmessige vurderinger og handlinger. Denne kan beskrives som en pragmatisk funksjonell phronesis posisjon eller skjønnsutøvelse. I tillegg ser vi i datamaterialet en kontinuerlig bevegelse mellom flere phronesis- nivåer og stadier i det kunstdidaktiske arbeidet. Tanker, følelser og handlinger kommer i spill og beveger i ulike refleksjonsnivåer som også inkluderer estetiske og etiske vurderinger og fordringer hos aktørene. Det å utøve kritisk dømmekraft, handle og reflektere over KunstInnsatsen i møte med asylsøkere, kan derfor i tillegg leses som utøvelse av en kritiskemansipatorisk phronesis. Slik vi leser felteksemplene gir KunstInnsatsen derfor mulighet for en omfordeling og nydannelse i møte et 'sanselige regime'. Og i forlengelsen et uttrykk for mening gjennom handling i en KunstInnsats. Den frivillige dugnadsinnsatsen i KunstInnsatsen igangsetter altså et stort register av skjønnsutøvelser hos de involverte partene og ser derfor ut til kunne å inngå i utviklingen av det kulturelle demokrati i Norge.

\section{Forfatterpresentasjon}

Jon Arnesen er universitetslektor ved barnevernspedagogutdanningen, Institutt for barnevern og sosialt arbeid UiT Campus Harstad. Hovedfag i forming 1986, allmennlærer 1981. Ansatt på Høgskolen i Harstad fra 2001. Har fagansvar for aktivitetsfaget ved barnevernspedagogutdanningen. Hovedinteresseområder er sosialpedagogikk, eksistensialisme, språkfilosofi og betydningen av estetisk 
erfaring.https://www.cristin.no/as/WebObjects/cristin.woa/wa/fres?sort=ar\&pnr=336607\&la=no\&acti on=sok

Rikke Gürgens Gjærum er professor i drama/teater ved HIOA og UIT. Dr.at. v/NTNU i 2004, hovedfag i teatervitenskap v/UIO i 1998, allmennlærer og dramapedagog. Arbeider med anvendt teaterforskning, disability art, reminisensteater, estetikkfilosofi og kunstbaserte forskningsmetoder, men også med teaterkritikk, barne- og ungdomsteater og ulike anvendte antistigmatiserende teaterprosjekter i «Usedvanlig teater». Gjærum har skrevet en rekke artikler og bøker, for liste se publikasjoner: https://www.cristin.no/as/WebObjects/cristin.woa/wa/fres?sort=ar\&la=no\&action=sok\&pnr=35801

\section{Referanser}

Aristoteles. (1999). Etikk: et hovedverk i Aristoteles' filosofi, også kalt "Den nikomakiske etikk" (3. utg.). Oslo: Gyldendal.

Arnesen, J. (2015a). Den estetiske skolen i fremtiden. Bedre Skole (3), 88-93. https://www2.utdanningsforbundet.no/upload/Tidsskrifter/Bedre\%20Skole/BS_3_2015/UTDBS0315-WEB2ny versjon 22sept Arnesen.pdf

Arnesen, J. (2015b). Erfaringens kontinuum - om ungdom og identitetsmarkører. InFormation Nordic Journal of Art and Research, 4(2), 23. Hentet fra http://dx.doi.org/10.7577/if.v4i2.1544

Aure, V. (2013). Didaktikk-i spennet mellom klassisk formidling og performativ praksis. InFormation-Nordic Journal of Art and Research, 2(1). Hentet fra http://dx.doi.org/10.7577/if.v2i1.611

Aure, V., \& Gjærum, R. G. (2015). Møter med marginale røster i kunstdidaktikken. Nordic Journal of Art and Research, Volume 4 (nr. 2). Hentet fra http://dx.doi.org/10.7577/if.v4i2.1539

Bjørkvold, J.-R. (2007 (1989)). Det musiske menneske. Oslo: Freidig forlag.

Bjørkvold, Ø. (2013). Møter mellom mennesker: innføring i interkulturell kommunikasjon (2. utg.). Oslo: Gyldendal Akademisk.

Delhey, J., \& Newton, K. (2003). Who trusts? The origins of social trust in seven societies. European Societies, 5(2), 93-137. Hentet fra http://dx.doi.org/10.1080/1461669032000072256

Engelstad, F. (2006). Makt i det norske samfunnet. I. K. Frønes, Lise (Red.), Det norske samfunn. Oslo: Gyldendal akademisk.

Giddens, A. (1984). The constitution of society: outline of the theory of structuration. Cambridge: Polity Press.

Gjærum, R. G. (2013). Applied Theatre Research: discourses in the field. European Scientific Journal, 3 Special edition December 2013.

Grimen, H. (2009). Hva er tillit. Oslo: Universitetsforlaget.

Gürgens, R. (2004). En usedvanlig estetikk: en studie av betydningen av egenproduserte teatererfaringer for det usedvanlige mennesket. NTNU, Institutt for Kunst og Medievitenskap, Trondheim.

Hansen, F. T. (2008). At stå i det åbne: dannelse gennem filosofisk undren og narvar. København: Hans Reitzel.

Hohr, H., \& Pedersen, K. (1996). Perspektiver på aestetiske laereprocesser. København: Dansklærerforeningen.

Horghagen, S. (2012). Theatre as meaning making of the self; the kingdom of the subjunctive. Ergoterapeuten, 55(2), 54-61.

Horghagen, S. (2016). Fra avmakt til makt over eget hverdagsliv gjennom kulturelle aktiviteter. Tidsskrift for psykisk helsearbeid, 12(01-02). Hentet fra http://dx.doi.org/10.18261/issn.15043010-2016-01-02-13

Horghagen, S., \& Josephsson, S. (2010). Theatre as liberation, collaboration and relationship for asylum seekers. Journal of Occupational Science, 17(3), 168-176. Hentet fra http://dx.doi.org/doi:10.1080/14427591.2010.9686691

In place of war. $(2017,12.05$.) Hentet fra http://www.inplaceofwar.net/

Jacobsen, D. I. (2005). Hvordan gjennomføre unders $\phi$ kelser? innføring i samfunnsvitenskapelig metode. Kristiansand: Høyskoleforlaget. 
Jerlang, E., \& Jerlang, J. (1996). Socialisering og habitus: individ, familie, samfund. København: Munksgaard-Rosinante.

Johannessen, A., Tufte, P. A., \& Christoffersen, L. (2006). Introduksjon til samfunnsvitenskapelig metode. Oslo: Abstrakt forlag.

Johannessen, K. (1984). Kunst, språk og handling. Norsk Filosofisk tidsskrift, 19(1), 9-41.

Kroksmark, T. (2006). Den tidløse pedagogikken. Bergen: Fagbokforlaget

Krüger, V., \& Strandbu, A. (2015). Musikk, ungdom, deltakelse: musikk i forebyggende arbeid. Oslo: Universitetsforlaget.

El Husseiny, B. (2016. 12.05.). Inn til kjernen - verdien av kunst og kultur. Kulturrådet.no. Foredrag Kulturrådets jubileumskonferanse i Harstad. Hentet fra http://www.kulturradet.no/documents/10157/7ec53f0e-7ea6-49a6-bc15-94deec95768e Original tekst: http://www.kulturradet.no/documents/10157/edf63905-893e-4eac-a94e-9ded46a677a9

Lysaker, O. (2011). Anerkjennelse og menneskeverdets forankring; henimot en transnasjonal anerkjennelsespolitikk. Etikk i praksis. Nordic Journal of Applied Ethics, 5(2), s. 101-122. http://dx.doi.org/10.5324/eip.v5i2.1773

Løvlie, L. (2003). Det nye pedagogikkfaget. Norsk pedagogisk tidsskrift, 87(1), 3-18.

Meyer, S. (2015). Kunst og etikk: en innføring. Oslo: Cappelen Damm akademisk.

Minde, A. (2000). Kunsten som sjelens arkitekt: kunst, galskap og terapi. Oslo: Gyldendal akademisk.

Paulsen, V., Berg, B., \& Michelsen, H. (2015). Barnevernets arbeid med barn i asylsøkerfasen. Tidsskriftet Norges barnevern, 91(03).

Rancière, J. (2004). Disagreement: politics and philosophy. Minneapolis, Minn: University of Minnesota Press.

Rancière, J. (2008). Estetikken som politikk: fra Malaise dans l'esthétique (2004). In K. B.-R. Bale, Arnfinn (Ed.), Estetisk teori. Oslo: Universitetsforlaget.

Rancière, J. (2012a). Den emansiperte tilskuer. Oslo: Pax forlag.

Rancière, J. (2012b). Sanselighetens politikk. Oslo: Cappelen Damm.

Ringdal, K. (2007). Enhet og mangfold: samfunnsvitenskapelig forskning og kvantitativ metode. Bergen: Fagbokforlaget.

Roaldsnes, Merete Hoel. (2017). Kva kan deltaking i ei musikkterapigruppe betyr for ungdommar som har bakgrunn som einslege mindreårige flyktningar? PH.D-prosjekt. https://vimeo.com/97516461

Ross, M. (1978). The creative arts. London: Heinemann Educational Publishers.

Ross, M. (1984). The aesthetic impulse. Oxford: Pergamon Press.

Storsve, V., Westbye, I. A. \& Ruud, E. (2010). Hope and recognition: A Music Project among Youth in a Palestinian Refugee Camp. Voices: A World Forum for Music Therapy, 10(1). http://dx.doi.org/10.15845/voices.v10i1.158

Thagaard, T. (2003). Systematikk og innlevelse: en innføring i kvalitativ metode (2. utg.). Bergen: Fagbokforlaget.

Thompson, J., Hughes, J., \& Balfour, M. (2009). Performance in place of war. London: Seagull Books.

Vedeler, L. (1999). Pedagogisk bruk av lek. Oslo: Universitetsforlaget.

Waaktaar, T. \& Christie, H. J. (2008). Styrk sterke sider: håndbok i resiliencegrupper for barn med psykososiale belastninger. Oslo: Pensumtjeneste.

Winnicott, D. W. (2003). Leg og virkelighed (2. utg.). København: Hans Reitzels Forlag.

Ødegaard, A. J. (2003). Kunst- og uttrykksterapi: fra kaos til form. Oslo: Universitetsforlaget. 